\title{
PERLINDUNGAN HUKUM TERHADAP KEBUDAYAAN BALI SEBAGAI SUMBER DAYA EKONOMI PARIWISATA
}

\author{
Oleh :
}

Made Suksma Prijandhini Devi Salain ${ }^{1}$

Fakultas Hukum Universitas Udayana

\begin{abstract}
Abstrak
Kebudayaan masyarakat hukum adat Bali merupakan sumber daya ekonomi bagi pariwisata. Sayangnya, masyarakat Bali relatif tidak dapat menikmati manfaat ekonomi tersebut. Pemerintah dan pengusaha jasa pariwisata merupakan pemangku kepentingan yang selama ini cenderung paling diuntungkan. Keadaan tersebut tentu membutuhkan penelusuran dan penelitian terhadap instrumen hukum yang mengatur kebudayaan, masyarakat, dan pariwisata. Selain itu, perlu juga dilakukan dianalisis terhadap isu mengenai apakah peraturan perundang-undangan nasional terkait sudah mengatur dan melindungi kebudayaan masyarakat hukum adat sebagai salah satu sumber daya ekonomi pariwisata. Penelitian ini merupakan penelitian hukum normatif yang utamanya menganalisis bahan hukum primer berupa peraturan perundangundangan. Hasil penelitian menunjukkan bahwa peraturan perundang-undangan nasional terkait hanya sebatas mengakui kebudayaan masyarakat adat. Bahkan peraturan-peraturan tersebut juga terlihat belum secara spesifik memberikan perlindungan hukum terhadap kebudayaan masyarakat hukum adat sebagai sumber daya ekonomi pariwisata. Artikel ini merekomendasikan kepada Pemerintah untuk merevisi peraturan perundang-undangan yang berlaku saat ini atau membentuk peraturan perundangan baru sebagai bentuk respon terhadap permasalahan ini.
\end{abstract}

Kata Kunci: kebudayaan, masyarakat hukum adat, Bali, sumber daya ekonomi, pariwisata.

Abstract

The culture of Balinese indigenous people is an economic resource for tourism. Unfortunately, the Balinese people are relatively unable to enjoy the economic benefits. Government and Tourism Service Entrepreneurs are stakeholders who tend to benefit the most. This situation necessarily requires inquiry and research to legal instruments governing culture, society, and tourism. In addition, it should also be analyzed on the issue of whether the relevant national legislation has regulated and protected the culture of indigenous people as one of the tourism economic resources. This writing is a normative legal research that primarily analyzes primary sources in the form of legislation and regulation. The results show that the relevant national legal instruments only recognize the culture of indigenous peoples. Such instruments seem also to be inadequate in providing legal protection to the culture of the indigenous peoples as tourism economic resources. This article recommends the Government to revise the existing laws or establish new legislation to address the issue in concern.

Keywords: culture, indigenous people, Bali, economic resource, tourism.

\section{Pendahuluan}

\subsection{Latar Belakang}

Sumber daya ekonomi merupakan faktor-faktor penting yang berkaitan dengan barang (goods) dan jasa (services). Sumber daya ekonomi terdiri dari faktor manusia, seperti tenaga kerja dan manajemen sedangkan faktor non-manusia terdiri dari tanah, modal, sumber finansial, teknologi, ${ }^{2}$ termasuk kebudayaan.

1 Made Suksma Prijandhini Devi Salain adalah Dosen Fakultas Hukum Universitas Udayana Denpasar. Korespondensi dengan penulis melalui email: suksmadevi@gmail.com

2 What are Economic Resources? Definition, Types and Examples, study.com/academy/lesson/what-are-economicresources-definition-types-examples.html 
Situasi yang selama ini berkembang di Bali menunjukkan betapa kebudayaan menjadi salah satu aset penting dalam penyelenggaraan usaha jasa pariwisata. Tidaklah dapat dipungkiri bahwa daya tarik kebudayaan ini telah menjadikan Bali sebagai destinasi wisata yang bereputasi. Dengan demikian, kebudayaan merupakan nilai fundamental dari penyelenggaraan pariwisata di Bali. ${ }^{3}$

Kebudayaan di Bali amat terkait dengan eksistensi masyarakat hukum adatnya. Selama ratusan tahun, mereka mengkreasikan kebudayaan yang sangat beragam dan tidak akan pernah bosan untuk dinikmati. Kebudayaan ini juga berpadu dengan keindahan alam di Bali.

Sistem religi sebagai salah satu unsur kebudayaan benar-benar tercermin di Bali. Upacaraupacara keagamaan yang dimulai dari kegiatan persembahyangan sehari-hari, upacara di pura/tempat persembahyangan secara reguler (odalan), upacara perkawinan, upacara potong gigi (metatah), upacara peresmian bangunan baru pemelaspasan, upacara kematian (ngaben), hingga seni gamelan, tari dan seni ukir/pahat benar-benar menjadi magnet bagi para wisatawan. Sebagai ilustrasi, setiap keluarga Hindu di Bali mengeluarkan uang sekitar Rp. 10.000,- (sepuluh ribu rupiah) setiap harinya untuk kegiatan persembahyangan. Jika diasumsikan terdapat 2.000.000 (dua juta) keluarga Hindu di Bali, maka hal ini berarti mereka mengeluarkan uangnya selama sebulan sejumlah Rp. 600.000.000.000,- dengan penghitungan Rp. $10.000 \times 2.000 .000 \times 30$ hari. ${ }^{4}$ Pengeluaran ini belumlah termasuk biaya yang perlu dikeluarkan untuk melakukan ritual jenis lainnya.

Dalam praktiknya, kebudayaan masyarakat adat Bali ini dikelola dan diselenggarakan secara mandiri oleh masyarakatnya, namun keuntungan dari usaha jasa pariwisata cenderung hanya dinikmati oleh pemerintah dan pengusaha jasa pariwisata. Dari sekian banyak biaya yang dikeluarkan oleh masyarakat adat Bali untuk memelihara dan mempertahankan kebudayaannya, nampaknya tidak ada timbal balik yang setimpal baik dari pemerintah maupun pengusaha jasa pariwisata. Hal ini disebabkan belum adanya hubungan ekonomi yang jelas di antara ketiga aktor dalam kebudayaan Bali, yang sekaligus pemangku kepentingan di bidang kepariwisataan, yakni pemerintah, pengusaha, dan masyarakat (adat).

Fenomena ini dapat diidentifikasikan bahwa di satu sisi, kebudayaan dimanfaatkan sebagai sumber daya ekonomi pariwisata, sedangkan di sisi lainnya, kebudayaan belum didefinisikan sebagai sumber daya ekonomi pariwisata. Pengabaian posisi ini tentu mengakibatkan kebudayaan berada dalam posisi yang rancu/tidak jelas. Kebudayaan secara diam-diam dimanfaatkan sebagai sumber daya ekonomi pariwisata, namun secara tidak langsung dibiarkan hancur dalam gempuran perbuatan para penyelenggara pariwisata. Perlakuan demikian mengakibatkan kerusakan berbagai penanda identitas kebudayaan Bali yang justru merupakan sendi-sendi fundamental kebudayaan Bali, seperti kerusakan sumber daya air, kerusakan

${ }^{3}$ Ida Bagus Wyasa Putra, Bali dalam Gempuran Ideologi Asing, Bali Post, 10 Januari 2011 (selanjutnya disebut Ida Bagus Wyasa Putra I), https://issuu.com/epaper-kmb/docs/bpo10012011

4 Ida Bagus Wyasa Putra.2015. “A Contra-productive Impact of Indonesian New Legislation on Administrative Village against Indonesian Indigenous Culture as an Economic Resources”, International Conference on Access to Justice for Indigenous Peoples, Malaysia: Faculty of Law University of Malaya, h. 2-3 (selanjutnya disebut Ida Bagus Wyasa Putra II). 
tata ruang dan lingkungan hidup, kemerosotan sikap/perbuatan dan kerusakan identitas kebudayaan Bali lainnya. ${ }^{5}$

Kebudayaan merupakan wacana yang terjebak di antara politik dan ekonomi. Sejak berdirinya Perserikatan Bangsa-Bangsa pada tahun 1945, diskusi kebudayaan berkaitan dengan penderitaan rakyat di Negara-negara bekas jajahan. Masyarakat internasional kemudian bersepakat untuk mencari cara pemulihan kebudayaan yang hancur akibat penjajahan dan Perang Dunia melalui bidang pendidikan dan ilmu pengetahuan yang justru menyebabkan kebudayaan itu sendiri terhenti pada visi substantif ilmu pengetahuan, pendidikan dan pengajaran. ${ }^{6}$ Pola tersebut menyebabkan kebudayaan terjebak di dalam format sains Cartesian (professional science), berisikan berbagai macam teori dan konsep, sangat ideal dalam wacana dan perdebatan namun miskin akan nilai/kegunaan dari kebudayaan itu sendiri. Pola yang demikian membuat kebudayaan berada pada 2 (dua) tempat yang berbeda, di satu sisi dikembangkan melalui keilmuan yang sangat ideal sedangkan di sisi lainnya dihancurkan melalui proses pembangunan yang sangat liar. Inilah dampak buruk dari sains Cartesian yang mengabaikan nilai/ kegunaan yang sesungguhnya dari kebudayaan. ${ }^{7}$

Posisi kebudayaan dalam realitas masyarakat hukum adat Bali memberikan inspirasi lebih jernih tentang posisi dan fungsi struktural serta fungsional (instrumental) kebudayaan dalam konteks kehidupan manusia. Di sinilah diperlukannya hukum untuk pemeliharaan dan keberlanjutan eksistensi serta penyelenggaraan dari fungsi-fungsi kebudayaan. Peluang pemeliharaan serta keberlanjutan kebudayaan Bali memang lebih besar namun seperti yang telah disebutkan di atas, kebudayaan tidak difungsikan sebagai salah satu sumber daya ekonomi pariwisata.

Dapat kiranya dikemukakan bahwa situasi ini terjadi karena tidak ada regulasi yang memberikan definisi, pengakuan, serta perlindungan kebudayaan sebagai sumber daya ekonomi pariwisata. Sebagai contoh, Undang-Undang No. 10 Tahun 2009 tentang Kepariwisataan (selanjutnya disebut dengan UU Kepariwisataan) yang tidak secara eksplisit mengakui dan melindungi kebudayaan sebagai sumber daya ekonomi pariwisata." Istilah 'budaya' termuat di dalam Pasal 1 (5) UU Kepariwisataan dalam suatu kerangka definisi Daya Tarik Wisata." Definisi yang kontras mengenai kebudayaan diberikan oleh Undang-Undang No. 11 Tahun 2010 tentang Cagar Budaya (selanjutnya disebut dengan UU Cagar Budaya), yang mana kebudayaan dianggap sebagai tanda peradaban/perkembangan manusia.

Demikian pula halnya dengan Pasal 1 (12) Peraturan Daerah Provinsi Bali No. 2 Tahun 2012 tentang Kepariwisataan Budaya Bali (selanjutnya disebut Perda Kepariwisataan Budaya Bali) yang lebih menekankan definisi kebudayaan kepada unsur-unsur terbentuknya suatu

5 Ida Bagus Wyasa Putra. 2011.“Kebudayaan Sebagai Sumber Daya Ekonomi: Memulihkan Identitas, Meningkatkan Kesejahteraan Umat Manusia”, Disampaikan pada Focus Group Discussion (FGD) dalam Bali World Culture Forum 2011, Denpasar: Dinas Kebudayaan Pemerintah Provinsi Bali, h. 11 (selanjutnya disebut Ida Bagus Wyasa Putra III).

6 Department of Public Information. 1989. Basic Facts About The United Nations. New York: United Nations, h. 189.

7 Ida Bagus Wyasa Putra III, Loc.Cit. 
kebudayaan tetapi tidak menunjukkan bahwa eksistensi kebudayaan sebagai salah satu sumber daya ekonomi pariwisata.

Sejumlah peraturan perundang-undangan yang disebutkan di atas sekali lagi menunjukkan bahwa belum ada yang memberikan definisi, memberikan pengakuan dan perlindungan terhadap kebudayaan sebagai sumber daya ekonomi pariwisata. Dengan kata lain, adanya kekosongan norma hukum yang mengatur, mengakui dan melindungi kebudayaan masyarakat hukum adat Bali sebagai salah satu sumber daya ekonomi pariwisata. Hal ini nampaknya disebabkan karena pemerintah masih menggunakan pendekatan klasik dalam pembuatan kebijakan untuk mengelola dan menyelenggarakan kebudayaan. Sementara itu, pihak masyarakat adat Bali mengelola kebudayaan sebagai bagian dari kehidupannya sehari-hari.

Perbedaan paradigma mengenai pengelolaan dan penyelenggaraan kebudayaan antara pemerintah dengan masyarakat hukum adat Bali tentu memerlukan pendekatan baru dalam pembentukan kebijakan terkait. Pelibatan Desa Adat/Desa Pekraman sebagai wadah dari masyarakat adat Bali dalam pengelolaan kebudayaan, program kebudayaan, biaya pengelolaan, pihak yang berhak mengelola dan menyelenggarakan kebudayaan, pihak yang berhak menikmati keuntungan dari penggunaan kebudayaan sebagai sumber daya ekonomi perlu diperjelas dalam kebijakan baru ini. Demikian pula halnya dengan penentuan hak dan kewajiban yang jelas kepada pemilik kebudayaan (masyarakat hukum adat Bali) dan pengguna kebudayaan (pemerintah dan pengusaha jasa pariwisata), sehingga mereka dapat berpartisipasi dalam pembangunan kebudayaan yang berkelanjutan.

\subsection{Tujuan Penulisan}

Ada 2 (dua) hal yang menjadi tujuan penulisan ini. Pertama, artikel ini hendak mengidentifikasi pengaturan hukum nasional dan lokal yang berkaitan dengan perlindungan terhadap eksistensi kebudayaan masyarakat hukum adat Bali. Berkaitan dengan tujuan yang pertama tersebut, tulisan ini juga dimaksudkan untuk menganalisis kekosongan norma pada pengaturan kebudayaan masyarakat hukum adat (Bali) yang melindungi kebudayaan sebagai sumber daya ekonomi pariwisata.

\section{3. $\quad$ Metode}

Metode yang digunakan di dalam artikel ini adalah penelitian hukum normatif yang utamanya meneliti bahan-bahan hukum primer, yakni berupa peraturan perundang-undangan di tingkat nasional dan lokal. Selain itu, diteliti pula bahan-bahan hukum sekunder ${ }^{8}$ yang berupa buku, jurnal, dan karya tulis hukum berkaitan dengan kebudayaan masyarakat hukum adat Bali dan sumber daya ekonomi pariwisata. Bahan-bahan hukum tersebut dikumpulkan dengan melakukan pencatatan dengan menggunakan card system yang selanjutnya dianalisis melalui langkah-langkah deskripsi, interpretasi (gramatikal, sistematisasi), argumentasi dan evaluasi.

8 Ronny Hanitijo Soemitro.1998. Metodelogi Penelitian Hukum dan Juru Metri. Jakarta: Penerbit Ghalia Indonesia, h. 12. 


\section{HASIL DAN PEMBAHASAN}

\subsection{Pengaturan Eksistensi Kebudayaan Masyarakat Hukum Adat (Bali) Berdasarkan Hierarki Peraturan Perundang-undangan di Indonesia}

Masyarakat hukum adat dan kebudayaannya tidak hanya dimiliki oleh Daerah Provinsi Bali saja, tetapi juga dimiliki oleh sejumlah daerah di Indonesia (umumnya). Oleh karena itu pengaturan eksistensi kebudayaan masyarakat adat (Bali) akan dilihat dari instrumen hukum nasional yang relevan. Hal ini bertujuan agar pembahasan penelitian menjadi sistematis, menegaskan bahwa kebudayaan masyarakat adat merupakan aset berharga yang diakui dan dimiliki oleh sebuah Negara sehingga perlu diatur secara hukum.

Indonesia menganut Stufenbau Theorie di dalam tata urutan peraturan perundangundangannya. Hal ini terlihat pada Undang-Undang No. 12 Tahun 2011 tentang Pembentukan Peraturan Perundang-undangan (selanjutnya disebut dengan UU Pembentukan Peraturan Perundang-Undangan Indonesia). Teori ini mengemukakan hierarki tata urutan peraturan perundang-undangan, yang mana peraturan yang lebih rendah harus mengacu kepada peraturan yang lebih tinggi, begitu seterusnya sampai pada grundnorm atau basic norm. Menurut Hans Kelsen, basic norm ${ }^{9}$ adalah:

"The basic norm of a dynamic system is fundamental rule according to which the norms of the system are to be created. A norm forms part of a dynamic system if it has been created in a way that is - in the last analysis - determined by the basic norm. A norm thus belongs to the religious system just given by way of example if it is created by God or originates in an authority having its power from God "delegated" by God". ${ }^{10}$ (Terjemahan bebas: Norma dasar dari sistem dinamik adalah aturan fundamental yang mengacu pada norma dari sistem yang harus dibentuk. Bentuk sebuah norma dari sistem dinamik dibuat dengan caranya seperti itu pada analisis terakhir ditentukan oleh norma dasar. Sebuah norma yang termasuk dalam sistem religius sebagai contoh diciptakan oleh Tuhan atau atau berasal dari kewenangan yang didelegasikan oleh Tuhan).

Kelsen memahami hukum sebagai suatu 'tatanan' sehingga grundnorm atau basic norm digunakan sebagai sumber hukum tertinggi bagi pembentukan peraturan perundang-undangan.

Berdasarkan Pasal 7 (1) UU Pembentukan Peraturan Perundang-undangan, tata urutan peraturan perundangan di Indonesia dimulai dari: Undang-Undang Dasar Negara Republik Indonesia Tahun 1945 (UUDNRI 1945), Ketetapan Majelis Permusyawaratan Rakyat (TAP MPR), Undang-Undang/Peraturan Pemerintah Pengganti Undang-Undang (UU/PERPPU),

9 “....the Procedure of creating the lower norm and the contents of this norm, the higher norm is 'applied' in the creation of the lower norm.....For a norm the creation of which is not determined at all by another norm cannot belong to any legal order..... The contents of the norm to be created are determined by a higher norm." Lihat Hans Kelsen. 2009. General Theory of Law and State, Translated by Anders Wedberg, Asistant Professor of Philosophy in the University of Stockholm, 3rd Printing, The Lawbook Exchange, Ltd., New Jersey, h. 133-134

10 Ibid., h. 113. 
Peraturan Pemerintah (PP), Peraturan Presiden (Perpres), Peraturan Daerah Provinsi dan Peraturan Daerah Kabupaten/Kota." Dengan demikian penjabaran peraturan perundangan terkait di bawah ini akan disesuaikan dengan hierarki peraturan perundangan berdasarkan Pasal 7 ayat (1) UU Pembentukan Peraturan Perundang-undangan.

\subsubsection{Undang-Undang Dasar Negara Republik Indonesia 1945}

UUDNRI 1945 merupakan konstitusi Indonesia yang mengakui keberadaan desa adat dan masyarakat hukum adatnya. Hal ini terlihat di dalam Pasal 18 B (2) yang menyatakan: "Negara mengakui dan menghormati kesatuan-kesatuan masyarakat hukum adat beserta hakhak tradisionalnya sepanjang masih hidup dan sesuai dengan perkembangan masyarakat dan prinsip Negara Kesatuan Republik Indonesia, yang diatur dalam undang-undang." Pengakuan konstitusional terhadap keberadaan desa Adat, termasuk yang sudah ada sebelum kemerdekaan Indonesia, tentu menjadikan desa Adat dan masyarakat hukum adatnya memiliki hak dan kewajiban yang sama seperti masyarakat Indonesia lainnya.

Hak-hak yang dimiliki oleh masyarakat adat di Indonesia sesungguhnya dijamin di dalam konstitusi. Pasal 28 C (1) UUDNRI 1945 menyatakan "Setiap orang ... berhak ...memperoleh manfaat dari ilmu pengetahuan dan teknologi, seni dan budaya, demi meningkatkan kualitas hidupnya dan demi kesejahteraan umat manusia." Selanjutnya, Pasal 28 I (3) UUDNRI 1945 menyatakan "Identitas budaya dan hak masyarakat tradisional dihormati selaras dengan perkembangan zaman dan peradaban.” Berkaitan dengan kebudayaan, Pasal 32 (1) UUDNRI 1945 yang menyatakan bahwa "Negara memajukan kebudayaan nasional Indonesia di tengah peradaban dunia dengan menjamin kebebasan masyarakat dalam memelihara dan mengembangkan nilai-nilai budayanya." Dari beberapa ketentuan di dalam UUDNRI 1945 tersebut dapat dimaknai bahwa masyarakat adat di Indonesia (termasuk masyarakat adat Bali) memiliki hak sekaligus kewajiban untuk memelihara, melestarikan, melindungi, mengembangkan dan tentunya menikmati keuntungan dari kebudayaan yang mereka miliki.

\subsubsection{Undang-Undang No. 39 Tahun 1999 tentang Hak Asasi Manusia}

Pasal 6 (1) dan (2) Undang-Undang No. 39 Tahun 1999 tentang Hak Asasi Manusia (selanjutnya disebut UU HAM) ini menyebutkan bahwa: "Dalam rangka penegakan hak asasi manusia, perbedaan dan kebutuhan dalam masyarakat hukum adat harus diperhatikan dan dilindungi oleh hukum, masyarakat, dan pemerintah; Identitas budaya masyarakat hukum adat, termasuk hak atas tanah ulayat dilindungi, selaras dengan perkembangan zaman." Ketentuan ini memberikan perlindungan kepada masyarakat hukum adat sama seperti masyarakat pada umumnya termasuk identitas budaya dari masyarakat hukum adat itu sendiri. Apabila pemerintah, investor, orang perorangan ataupun kelompok orang yang tidak menghormati serta melidungi keberadaan masyarakat hukum adat maka pihak yang bersangkutan dapat dikatakan telah melakukan pelanggaran HAM terhadap masyarakat hukum adat tersebut. Dengan demikian sesungguhnya Negara telah memberikan perlindungan terhadap kebudayaan yang 
dimiliki oleh masyarakat hukum adat namun tidak jelas mengenai status beserta sistem pengelolaannya. Ketidakjelasan tersebut akan diuraikan pada bagian berikut ini.

\subsubsection{Undang-Undang No. 10 Tahun 2009 tentang Kepariwisataan}

Instrumen hukum nasional ketiga yang berkaitan dengan eksistensi kebudayaan masyarakat adat sebagai sumber daya ekonomi adalah UU Kepariwisataan. Konteks pariwisata di Bali secara khusus dan Indonesia secara umumnya tidaklah dapat terlepas dari kebudayaan. Berdasarkan Pasal 1 (5) UU Kepariwisataan, "Daya tarik wisata adalah segala sesuatu yang memiliki keunikan, keindahan, dan nilai yang berupa keanekaragaman kekayaan alam, budaya, dan hasil buatan manusia yang menjadi sasaran atau tujuan kunjungan wisatawan.” Bunyi ketentuan ini secara eksplisit menyebutkan budaya (yang juga dimiliki oleh masyarakat adat) sebagai salah satu daya tarik wisata yang dimiliki oleh Indonesia. Hal ini tentu sejalan dengan UUD NRI tahun 1945 dan UU HAM yang mengakui dan melindungi kebudayaan (termasuk identitas budaya yang dimiliki oleh masyarakat hukum adat).

Kebudayaan adalah kekuatan terbesar yang dimiliki oleh Indonesia (pada umumnya) dan Bali (pada khususnya) untuk menarik minat wisatawan domestik maupun asing datang ke Indonesia. Mengingat begitu pentingnya kebudayaan bagi Indonesia, khususnya Bali, maka kepariwisataan hendaknya senantiasa memperhatikan aspek HAM, keanekaragaman budaya, dan kearifan lokal, sebagaimana digariskan oleh Pasal 5 UU Kepariwisataan.

Penyelenggaraan kepariwisataan harus memberdayakan masyarakat setempat, karena sesungguhnya merekalah yang benar-benar mengetahui kebudayaan tersebut, bagaimana cara melestarikannya agar tetap bisa dijadikan sebagai salah satu sumber daya ekonomi pariwisata. Kebudayaan yang dijaga, dilestarikan dan dikelola dengan tepat akan memberi faedah bagi kesejahteraan rakyat. Dengan demikian, perbedaan dalam pengembangan/pembangunan kebudayaan di sejumlah daerah di Indonesia merupakan keniscayaan karena masing-masing daerah memiliki kondisi geografis, ciri khas, dan kultur yang amat beragam. Seperti misalnya di Bali, kebudayaan yang menonjol adalah pola kehidupan masyarakatnya (kehidupannya sehari-hari sampai dengan kegiatan-kegiatan adat yang mereka miliki) termasuk tempat-tempat ibadah/ persembahyangannya (pura). Hal ini tentu sesuai dengan isi Pasal 6 UU Kepariwisataan yang menggariskan bahwa pembangunan kepariwisataan memperhatikan kekhasan budaya.

\subsubsection{Undang-Undang No. 11 Tahun 2010 tentang Cagar Budaya}

Pasal 1 (1) UU Cagar Budaya cenderung mengatur kebudayaan dalam bentuk benda berwujud karena mengkonsepkan cagar budaya sebagai suatu adalah warisan budaya yang bersifat kebendaan. Pada bagian menimbang huruf (a) UU Cagar Budaya dinyatakan bahwa "cagar budaya merupakan kekayaan budaya bangsa ... yang penting artinya bagi pemahaman dan pengembangan ... kebudayaan... sehingga perlu dilestarikan dan dikelola secara tepat melalui upaya pelindungan, pengembangan, dan pemanfaatan dalam rangka memajukan kebudayaan nasional untuk sebesar-besarnya kemakmuran rakyat." 
Sejumlah ketentuan pada UU Cagar Budaya juga menunjukkan bahwa benda cagar budaya perlu dilindungi, dikembangkan dan dimanfaatkan guna memajukan kebudayaan nasional yang pada akhirnya untuk kemakmuran dan kesejahteraan rakyat. Pernyataan tersebut sesungguhnya memberikan pengakuan bahwa benda cagar budaya memiliki peranan/fungsi untuk mewujudkan kemakmuran/kesejahteraan rakyat namun tidak ada satu pun ketentuan yang menyatakan bahwa kebudayaan merupakan salah satu sumber daya ekonomi. UU Cagar Budaya hanya mengatur warisan budaya yang berupa kebendaan, seperti bangunan-bangunan bersejarah.

\subsubsection{Peraturan Daerah Provinsi Bali No. 2 Tahun 2012 tentang Kepariwisataan Budaya Bali}

Kebudayaan berdasarkan Pasal 1 (12) Perda Kepariwisataan Budaya Bali adalah keseluruhan gagasan, perilaku dan hasil karya manusia dan/atau kelompok manusia baik bersifat fisik maupun non fisik yang diperoleh melalui proses belajar dan adaptasi terhadap lingkungannya. Dari pengertian tersebut, kebudayaan dianggap sebagai cipta, rasa dan karya manusia baik yang berwujud maupun tidak berwujud. Sama sekali tidak ada pernyataan yang menyebutkan bahwa kebudayaan memiliki nilai ekonomi bagi kehidupan masyarakat Bali sehingga menjadi salah satu sumber daya ekonomi pariwisata.

Pembangunan Kepariwisataan Budaya Bali meliputi 4 (empat) pilar, yaitu: usaha pariwisata; destinasi pariwisata; pemasaran; dan kelembagaan kepariwisataan, sebagaimana ditentukan di dalam Pasal 6 Perda Kepariwisataan Budaya Bali. Keempat pilar ini sejalan dengan yang diatur dalam UU Kepariwisataan namun cenderung memberikan ruang lebih kepada para Pengusaha Pariwisata bukan kepada masyarakat adat Balinya. Pembangunan usaha pariwisata tidak mungkin dapat dilaksanakan jika di daerah tersebut tidak memiliki sesuatu yang unik, seperti kebudayaan masyarakat adatnya.

2.2 Kekosongan Norma pada Pengaturan Kebudayaan Masyarakat Hukum Adat (Bali) yang Melindungi Kebudayaan sebagai Sumber Daya Ekonomi Pariwisata

Berdasarkan peraturan perundangan Indonesia yang telah disebutkan di atas, kebudayaan, pariwisata dan masyarakat adat memang diakui, dihormati dan telah diatur keberadaannya. Pengaturan kebudayaan yang ada sebatas identitas budaya sebuah masyarakat adat dan sebagai daya tarik pariwisata Indonesia namun belum ada pengaturan yang memberikan definisi kebudayaan sebagai salah satu sumber daya ekonomi. Keadaan ini menunjukkan adanya norma kosong pada pengaturan kebudayaan masyarakat hukum adat yang belum mengakui serta melindungi kebudayaan sebagai salah satu sumber daya ekonomi pariwisata. Dengan kata lain dapat dikatakan bahwa peraturan perundangan di Indonesia belum cukup/memadai untuk melindungi eksistensi kebudayaan masyarakat adatnya.

Kekosongan norma hukum yang diakibatkan oleh ketiadaan peraturan perundangan yang menggaransi perlindungan hukum bagi kebudayaan masyarakat adat sebagai salah satu 
sumber daya ekonomi pariwisata dapat diselesaikan melalui pembuatan peraturan perundangundangan terkait. Upaya ini merupakan jalan keluar yang dapat ditawarkan dari sudut pandang peneliti hukum normatif/akademik. Dari sudut pandang hakim, jalan keluarnya adalah penemuan hukum (rechtsvinding) melalui metode penafsiran interpretasi gramatikal, teleologis, sistematis, historis, komparatif dan interpretasi futuristis. ${ }^{11}$ Metode-metode penemuan hukum ini juga digunakan oleh para peneliti hukum untuk menganalisis peraturan perundang-undangan terkait permasalahan hukum sehingga sampai pada kesimpulan bahwa adanya suatu konflik norma, kekaburan norma ataupun kekosongan hukum.

Dari sudut pandang peneliti hukum normatif, pembentukan norma baru dalam bentuk peraturan perundangan yang sesuai berfungsi sebagai hukum yang dicita-citakan atau yang sering disebut dengan ius contituendum. ${ }^{12}$ Dalam hal ini, pemerintah dapat merevisi UU Kepariwisataan dengan menambahkan beberapa norma mengenai kebudayaan sebagai sumber daya ekonomi pariwisata (mulai dari definisi, pemanfaatan dan pengelolaannya) atau pun dapat membentuk peraturan perundangan baru yang secara khusus (lex specialist) mengatur kebudayaan sebagai salah satu sumber daya ekonomi pariwisata.

Menurut Bagir Manan, pembentukan suatu perundang-undangan harus memperhatikan 3 (tiga) hal fundamental agar memiliki kekuatan mengikat secara hukum dan dapat diberlakukan bagi masyarakat, yaitu dasar filosofis, yuridis, dan sosiologis. ${ }^{13}$

1) Dasar filosofis dalam pembentukan peraturan perundangan yang pertama berkaitan dengan rechtsidee (cita hukum), yakni pada dasarnya hukum adalah aturan tingkah laku bagi masyarakat yang bersumber dari pikiran, ide, gagasan, rasa, karsa dan cipta masyarakat itu sendiri. ${ }^{14}$ Cita hukum merupakan jiwa bangsa Indonesia yang digunakan sebagai norma dasar (grundnorm) dalam pembentukan segala peraturan perundang-undangan. Cita hukum bangsa Indonesia adalah Pancasila. Pancasila inilah yang digunakan sebagai norma dasar untuk membentuk peraturan perundangan mengenai kebudayaan sebagai salah satu sumber daya ekonomi pariwisata. Di dalam Pancasila termuat tujuan hukum untuk memberikan kemanfaatan, keadilan dan kepastian hukum bagi seluruh rakyat Indonesia sehingga peraturan perundangan kebudayaan yang dibuat dapat diberlakukan sah secara hukum. Di samping cita hukum maka nilai guna/manfaat (aksiologi) dari kebudayaan sebagai salah satu sumber daya ekonomi pariwisata-lah yang menjadi landasan filosofis pembentukan peraturan perundangan yang baru. Nilai guna di sini maksudnya bahwa kebudayaan selain sebagai identitas suatu peradaban,

11 Lihat Sudikno Mertokusumo dan A. Pitlo. 1993. Bab-Bab tentang Penemuan Hukum, Bandung: PT Citra Aditya Bakti, h. 14-19.

12 I Made Pasek Diantha. 2016. Metodologi Penelitian Hukum Normatif. Jakarta: Kencana Prenada Media Group, h. 120.

13 Bagir Manan, 1992. Dasar-dasar Perundang-undangan Indonesia. Jakarta: Ind-Hill. Co, h. 13-18..

14 Badan Pembinaan Hukum Nasional dari Masa ke Masa, BPN, 1995, h. 247 dalam Kurnisar, 2012, Pancasila Sebagai Sumber dari Segala Sumber Hukum di Indonesia, http://ejournal.undiksha.ac.id/index.php/MKFIS/article/view/467. Vol. 11 No. 3, h. 248. 
masyarakat/daerah, kebudayaan juga mempunyai manfaat untuk meningkatkan kesejahteraan masyarakat hukum adat sebagai pemilik kebudayaan.

Dasar filosofis kedua yang harus diperhatikan apakah karakteristik dari kebudayaan dan sumber daya ekonomi sebagi obyek dari peraturan perundangan yang baru. Setiap obyek pengaturan memiliki karakteristik tersendiri sehingga diperlukan konstruksi karakteristik dari obyek pengaturan tersebut. ${ }^{15}$ Hal ini dimaksudkan untuk menghindari ambiguitas-normatif (normative ambiguity) ${ }^{16}$ yang dapat menimbulkan problem konsep suatu obyek pengaturan. Ketidakjelasan dalam perumusan suatu peraturan perundang-undangan di Indonesia seringkali disebabkan oleh problem konsep. Problem konsep adalah problem tentang konsep yang berakar pada problem definisi. ${ }^{17}$ Problem definisi disebabkan oleh problem ketidaksesuaian antara definisi obyek dengan karakteristik obyek. Problem konsep merupakan penyebab utama problem pengaturan, problem pengaturan merupakan akar problem konstruksi norma, struktur dan substansi norma. Problem konstruksi norma merupakan penyebab utama problem fungsi dan perwujudan tujuan-tujuan hukum. ${ }^{18}$

Penentuan karakteristik obyek pengaturan ini dapat dilakukan dengan analisis terminologi, analisis pengertian, analisis konsep tentang konsep obyek pengaturan, analisis konsep pengaturan, analisis pelingkupan materi dan konstruksi materi pengaturan serta analisis konstruksi norma. ${ }^{19}$ Dengan mengetahui karakteristik obyek pengaturan maka dapat ditentukan bentuk pengaturannya sehingga dapat mewujudkan tujuan-tujuan hukum. Adapun beberapa konsep yang terkait dengan perumusan/pembentukan peraturan perundangan mengenai kebudayaan sebagai sumber daya ekonomi ekonomi pariwisata, yaitu: konsep pembentukan peraturan perundang-undangan itu sendiri, konsep kesatuan masyarakat hukum adat, konsep kebudayaan, konsep sumber daya ekonomi dan konsep pariwisata. Konsep-konsep ini terlahir dari definisi/pengertian kesatuan masyarakat hukum adat, kebudayaan, sumber daya ekonomi dan pariwisata yang digunakan sebagai dasar untuk mengetahui karakteristik dari obyek pengaturan.

15 Myres S. McDougal. 1956. Law as a Process of Decision: A Policy-Oriented Approach to Legal Study. Yale Law School Scholarship Resipotory, h. 59 dan Ida Bagus Wyasa Putra. 2016. Teori Hukum dengan Orientasi Kebijakan (Policy-Oriented Theory of Law): Pemecahan Problem Konteks dalam Proses Legislasi Indonesia, Denpasar: Penerbit Udayana University Press, h. 177-179 (Selanjutnya disebut Ida Bagus Wyasa Putra IV)

16 "By this mean that such theory seeks in a single confused statement to perform multiple intellectual tasks. Thus, the ordinary legal rule or concept seeks, at one and the same time, to describe what decision-makers have done in the past, to predict what they will do in the future, and to prescribe what they ought to do", Lihat Myres S. McDougal, Ibid., h. 59.

${ }^{17}$ Akira Iida. 2004. Paradigm Theory \& Policy Making: Reconfiguring The Future, Singapore: Tuttle, h. 17, Baca juga: Myress S. McDougal. 1956. Law as a Process of Decision: A Policy-Oriented Approach to Legal Study. Faculty of Scholarship Series, h. 59.

18 Ida Bagus Wyasa Putra. 2010. Fungsi hukum Dalam Pengaturan Pariwisata Sebagai Bentuk Perdagangan Jasa, Disertasi, Prorgram Doktor Ilmu Hukum, Universitas Brawijaya, h. 437-438 (Selanjutnya disebut Ida Bagus Wyasa Putra V)

19 Ida Bagus Wyasa Putra II, Op.Cit., h. 182. 
2) Landasan yuridis pembentukan peraturan perundang-undangan memuat hal-hal berikut: ${ }^{20}$ Pertama, kewenangan dari pihak/lembaga yang membuat/membentuk peraturan perundangan. Kedua, adanya kesesuaian antara bentuk peraturan perundangan yang dibuat dengan materi yang diatur. Ketiga, syarat mutlak untuk mengikuti tata cara tertentu, lembaga yang berhak membentuk Peraturan Daerah (PERDA), UU yang telah dibentuk harus dimuat di dalam Lembaran Negara Republik Indonesia. Keempat, berpedoman pada Stufenbau Theorie dari Hans Kelsen, sebagaimana dijelaskan sebelumnya pada 2.1, yang menekankan tidak adanya pertentangan norma secara hierarki.

Fenomena di masyarakat menunjukkan bahwa kebudayaan merupakan salah satu sumber daya ekonomi pariwisata yang dapat digunakan untuk meningkatkan kesejahteraan masyarakat. Sesuai dengan salah satu tujuan Negara Indonesia yang termuat dalam UUD 1945 (berlandaskan pada Pancasila sebagai cita hukum bangsa Indonesia).Alinea IV Pembukaan UUDNRI 1945 menyatakan: “....Pemerintah Negara Indonesia yang melindungi segenap bangsa Indonesia dan seluruh tumpah darah Indonesia dan untuk memajukan kesejahteraan umum.....", sudah sepantasnya kebudayaan masyarakat adat di Indonesia (umumnya) dan di Bali (khususnya) harus dilindungi, dikelola, dipelihara, dilestarikan dengan diawali pembentukan peraturan yang tepat dengan karakteristik kebudayaan masyarakat adat itu sendiri.

Kebudayaan masyarakat adat di Indonesia tentunya akan berbeda dengan kebudayaan masyarakat adat di Australia dengan suku Aboriginnya atau kebudayaan masyarakat adat di Amerika dengan suku Indiannya. Masing-masing kebudayaan di suatu daerah atau Negara memiliki karakteristiknya masing-masing sehingga perlakuannya pun akan berbeda-beda. Karakteristik suatu kebudayaan dapat diketahui oleh pemilik kebudayaan itu sendiri, seperti masyarakat adat bukan oleh pihak lain, seperti pelaku usaha jasa pariwisata, investor asing ataupun Pemerintah. Masyarakat adat-lah yang mengetahui bagaimana seharusnya kebudayaan mereka dilindungi, dipelihara, dijaga dan dilestarikan agar kebudayaan itu tetap hidup sebagai penanda keberadaan mereka sekaligus sebagai sumber daya ekonomi.

Berdasarkan Pasal 5 huruf e UU Kepariwisataan, secara tersirat disebutkan bahwa "kepariwisataan diselenggarakan dengan prinsip memberdayakan masyarakat setempat." Kemudian Pasal 19 Ayat (1) huruf d memberikan pengakuan berkaitan dengan hak untuk memiliki peran di dalam pembangunan kepariwisataan. Istilah 'setiap orang' sebagai pemegang hak (right holder) dalam ketentuan ini dapat dimaknai sebagai setiap individu tanpa terkecuali termasuk masyarakat adat yang ada di Indonesia. Kedua pasal tersebut tentu memberikan suatu penegasan terkait dengan hak yang dimiliki masyarakat hukum adat untuk turut serta dalam proses pembangunan dan perdagangan jasa pari-

20 Bagir Manan,1992, Op.Cit, h. 14-15. 
wisata. Pasal tersebut sudah diimplementasikan untuk membangun kepariwisataan di Indonesia namun hanya sebatas keterlibatan masyarakat adat dalam pembangunan tidak sampai pada tahap menikmati keuntungan dari pembangunan kepariwisataan.

3) Dasar sosiologis dalam pembentukan peraturan perundangan mengenai kebudayaan sebagai sumber daya ekonomi pariwisata merupakan dasar yang mencerminkan bahwa dalam realitas kehidupan kebudayaan masyarakat adat memang benar adanya merupakan salah satu sumber daya ekonomi pariwisata. Masyarakat adat membutuhkan sebuah peraturan hukum yang jelas untuk melindungi kebudayaan mereka sekaligus tetap memberikan kesejahteraan bagi mereka. Keadaan ini merupakan kebutuhan dan ekspektasi dari masyarakat adat. Peraturan perundang-undangan yang disusun, dirumuskan, dibentuk berdasarkan kebutuhan dan ekspektasi masyarakat adalah peraturan hukum yang benar-benar valid dan dapat diimplementasikan di tengah masyarakat.

\section{PENUTUP}

\subsection{Kesimpulan}

a. Di Indonesia, pengaturan mengenai kebudayaan masyarakat adat telah termaktub di dalam sejumlah peraturan perundang-undangan nasional di Indonesia, yakni dari Undang-Undang Dasar Negara Republik Indonesia Tahun 1945, Undang-Undang No. 39 Tahun 1999 tentang Hak Asasi Manusia, Undang-Undang No. 10 Tahun 2009 tentang Kepariwisataan dan Undang-Undang No. 11 Tahun 2010 tentang Cagar Budaya. Eksistensi kebudayaan masyarakat adat Bali pun sudah diatur melalui Peraturan Daerah Provinsi Bali No. 2 Tahun 2012 tentang Kepariwiwsataan Budaya Bali.

b. Pengaturan kebudayaan masyarakat hukum adat di Indonesia (umumnya) dan di Bali (khususnya) belum mengatur secara spesifik mengenai perlindungan hukum kebudayaan sebagai salah satu sumber daya ekonomi pariwisata. Berbagai peraturan yang telah dibahas sebelumnya menunjukkan bahwa tidak terdapat peraturan yang memberikan pengertian bahwa kebudayaan adalah salah satu sumber daya ekonomi pariwisata. Pembentukan peraturan perundangan mengenai kebudayaan sebagai salah satu sumber daya ekonomi memperhatikan 3 (tiga) dasar, yakni: filosofis, yuridis dan sosiologis. Dari dasar filosofis, pembentukan peraturan perundangan kebudayaan sebagai sumber daya ekonomi harus memperhatikan cita hukum sebagai grundnorm (Pancasila) dan karakteristik dari obyek yang diatur guna menghindari terjadinya problem konsep. Dari dasar yuridis, peraturan perundangan yang akan dibentuk harus dibuat oleh Pejabat/Badan yang memang memiliki kewenangan untuk itu dan materi dari peraturan yang lebih rendah tidak boleh memuat pertentangan norma secara hierarki. Dari dasar sosiologis bahwa pembentukan peraturan perundangan terkait harus benar-benar berdasarkan kebutuhan dan ekspektasi masyarakat adat sebagai pemilik kebudayaan agar keuntungan dari kebudayaan yang mereka miliki dapat dinikmati oleh mereka bukan hanya oleh Pemerintah dan para pelaku usaha jasa pariwisata seperti selama ini. 


\subsection{Saran}

Pemerintah disarankan untuk segera merevisi peraturan perundangan yang sudah ada (UU Kepariwisataan) atau membuat peraturan perundangan baru yang khusus mengatur mengenai pengelolaan kebudayaan masyarakat adat sebagai salah satu sumber daya ekonomi. Dengan demikian kebudayaan masyarakat adat akan terlindungi, terpelihara dan terkelola dengan baik sehingga semua stakeholders dan masyarakat adat mendapatkan keuntungan. Keuntungan ini digunakan kembali untuk memelihara dan melindungi kebudayaan masyarakat hukum adat sehingga hak ekonomi, sosial dan budaya dari masyarakat hukum adat saling terkait dan mendukung satu dengan lainnya.

\section{DAFTAR PUSTAKA}

\section{A. Buku}

Cohen, Moris L. and Kent C Olcon. 2000.Legal Research in a Nutshell.Seven Edition, ST Paul Minn.

Department of Public Information. 1989. Basic Facts About The United Nations, New York:United Nations.

Diantha, I Made Pasek. 2016. Metodologi Penelitian Hukum Normatif. Jakarta: Kencana Prenada Media Group.

Iida, Akira. 2004. Paradigm Theory \& Policy Making: Reconfiguring The Future, Singapore: Tuttle.

Kelsen, Hans. 2009. General Theory of Law and State, Translated by Anders Wedberg, Assistant Professor of Philosophy in the University of Stockholm, The Lawbook Exchange, Ltd., New Jersey, 3rd Printing

Manan, Bagir. 1992. Dasar-Dasar Perundang-undangan Indonesia. Jakarta: Penerbit Ind-Hill.Co

McDougal, Myres S. 1956. Law as a Process of Decision: A Policy-Oriented Approach to Legal Study. Yale Law School Scholarship Resipotory.

Mertokusumo, Sudikno dan Mr. A. Pitlo. 1993. Bab-Bab tentang Penemuan Hukum, Bandung: PT Citra Aditya Bakti.

Nasution. 1998. Metode Penelitian Naturalistik Kualitatif. Bandung: Penerbit Tarsito.

Putra, Ida Bagus Wyasa. 2016. Teori Hukum Dengan Orientasi Kebijakan (Policy-Oriented Theory of Law): Pemecahan Problem Konteks Dalam Proses Legislasi Indonesia. Denpasar: Penerbit Udayana University Press.

Putra, Ida Bagus Wyasa, dkk. 2003, Hukum Bisnis Pariwisata. Bandung:Penerbit Refika Aditama. 
KERTHA PATRIKA

Volume 39, Nomor 1, April 2017

Ronny Hanitijo Soemitro 1998. Metodelogi Penelitian Hukum dan Juru Metri. Jakarta: Penerbit Ghalia Indonesia.

Surakhmad, Winarno. 1972. Pengantar Penelitian Ilmiah, Dasar, Metode dan Teknik. Bandung: Penerbit Tarsito

\section{B. JURNAL}

Kurnisar, Pancasila Sebagai Sumber Dari Segala Sumber Hukum di Indonesia, http://ejournal.undiksha.ac.id/index.php/MKFIS/article/view/467, 2012, Vol. 11 No. 3.

\section{DISERTASI}

Ida Bagus Wyasa Putra, 2010, Fungsi hukum Dalam Pengaturan Pariwisata Sebagai Bentuk Perdagangan Jasa, Disertasi, Prorgram Doktor Ilmu Hukum, Universitas Brawijaya.

\section{MAKALAH}

Ida Bagus Wyasa Putra. 2015. "A Contra-productive Impact of Indonesian New Legislation on Administrative Village against Indonesian Indigenous Culture as an Economic Resources", International Conference on Access to Justice for Indigenous Peoples, Malaysia: Faculty of Law University of Malaya. . 2011. Kebudayaan Sebagai Sumber Daya Ekonomi : Memulihkan Identitas, Meningkatkan Kesejahteraan Umat Manusia, Disampaikan pada Focus Group Discussion (FGD) dalam Bali World Culture Forum 2011, Denpasar: Dinas Kebudayaan Pemerintah Provinsi Bali.

\section{E. ARTIKEL MEDIA MASSA}

Ida Bagus Wyasa Putra, Bali Dalam Gempuran Ideologi Asing, Bali Post, 10 Januari 2011. https://issuu.com/epaper-kmb/docs/bpo10012011

\section{F. ARTIKEL INTERNET}

What are Economic Resources? Definition, Types and Examples, study.com/academy/lesson/what-areeconomic-resources-definition-types-examples.html. 


\section{G. PERATURAN PERUNDANG-UNDANGAN}

Undang-Undang Dasar Negara Republik Indonesia1945.

Undang-Undang No. 39 Tahun 1999 tentang Hak Asasi Manusia, Lembaran Negara Republik Indonesia Tahun 1999 Nomor 65,Tambahan Lembaran Negara Republik Indonesia Nomor 3886.

Undang-Undang No. 10 Tahun 2009 tentang Kepariwisataan, Lembaran Negara Republik Indonesia Tahun 2009 Nomor 11, Tambahan Lembaran Negara Republik Indonesia Nomor 4996.

Undang-Undang No. 11 Tahun 2010 tentang Cagar Budaya, Lembaran Negara Republik Indonesia Tahun 2010 Nomor 130, Tambahan Lembaran Negara Republik Indonesia Nomor 5168

Peraturan Daerah Provinsi Bali No. 2 Tahun 2012 tentang Kepariwisataan Budaya Bali, Lembaran Daerah Provinsi Bali Tahun 2012 Nomor 2, Tambahan Lembaran Daerah Provinsi Bali Nomor 2. 